Canadian Journal of Applied Linguistics

Revue canadienne de linguistique appliquée

\title{
Introduction to the Special Issue
}

\section{Marie-Josée Hamel and Jennifer St. John}

Volume 22, Number 1, 2019

Special Issue: In Memory of Larry Vandergrift

Numéro spécial : à la mémoire de Larry Vandergrift

URI: https://id.erudit.org/iderudit/1060903ar

DOI: https://doi.org/10.7202/1060903ar

See table of contents

Publisher(s)

University of New Brunswick

ISSN

1920-1818 (digital)

Explore this journal

Cite this document

Hamel, M.-J. \& St. John, J. (2019). Introduction to the Special Issue. Canadian Journal of Applied Linguistics / Revue canadienne de linguistique appliquée, 22(1). https://doi.org/10.7202/1060903ar 


\title{
Dr. Laurens (Larry) Vandergrift (1946-2015)
}

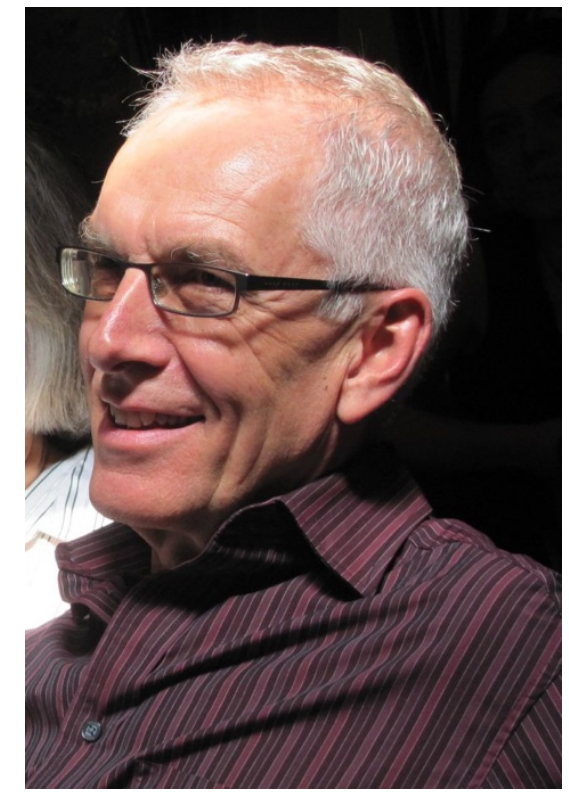

\section{Introduction to the Special Issue}

\author{
Marie-Josée Hamel \\ Official Languages and Bilingualism Institute, University of Ottawa \\ Jennifer St. John \\ Official Languages and Bilingualism Institute, University of Ottawa
}

\section{Part 1}

\section{Dr. Laurens (Larry) Vandergrift}

This Special Issue of the Canadian Journal of Applied Linguistics, In Memory of Larry Vandergrift is in honour of Larry Vandergrift's important and long-standing contributions to second language (L2) research and teaching and underlines the significant role our late colleague played in the field.

Larry Vandergrift was a Full Professor with the Official Languages and Bilingualism Institute (OLBI) of the Faculty of Arts at the University of Ottawa from 2002 to 2012 and was cross-appointed to the Faculty of Education. A language teacher and a researcher at OLBI, Larry Vandergrift taught language courses as well as courses in L2 teaching and acquisition at the undergraduate and graduate level. He worked as a consultant with the government and continued to work on projects for both the Canadian Association of Second Language Teachers and Canadian Parents for French. Larry Vandergrift began his career as a French as second language (FSL) teacher in Edmonton, Alberta, Canada. He received a Ph.D. in Second Language Education from the University of Alberta. Prior to this, he completed a Master of Education degree in Second Language Teaching (University 
of Ottawa) in 1985, a Bachelor of Library Science degree (University of Alberta) in 1975, and a Bachelor of Education degree in French, minor in German (Calvin College, MI) in 1969.

In 1992, Larry Vandergrift completed his doctoral research project on the topic of comprehension strategies of L2 French listeners, a field he would continue to research for the next two decades. He sought to understand the role and impact of listening strategies in second and foreign language learning and to help learners become better listeners. His experience as a language teacher, teacher trainer, and researcher gave him an integrated perspective on L2 acquisition and pedagogy. The results of his groundbreaking research in listening and metacognition have guided classroom practices and informed pedagogy in second and foreign language learning and teaching. At the heart of his research is the link of theory with practice. In his 2012 publication with Goh, the principles and practice of listening comprehension strategies are brought together, with a view to "helping teachers understand the process of listening, the role of metacognition in listening and how to teach listening more effectively" (Vandergrift \& Goh, 2012, p. xiii). Given this focus on the application of theoretical principles, his research, publications, and presentations have had a positive impact on the field of language teaching and learning and have earned him the highest respect from his peers. Larry Vandergrift was a much valued and respected member of the community of L2 teachers and researchers in Canada and internationally.

Larry Vandergrift led and participated in numerous projects at the national and international level. As a renowned researcher, he conducted research in the specific areas of first language (L1) listening comprehension, L2 proficiency, metacognition, sound discrimination ability, and working memory capacity. Of special note and relevance to research into metacognition and listening is his design and development of the Metacognitive Awareness of Listening Questionnaire (MALQ; Vandergrift, Goh, Mareschal, \& Tafaghodtari, 2006). His work on implementing the Common European Framework of Reference for Languages (CEFR) and the Diplôme d'études en langue française (DELF) in the FSL curriculum in Canada has had a profound impact on Canadian FSL classrooms.

Over the course of Larry Vandergrift's career, his externally-funded research projects, many of which were funded by the Social Sciences and Humanities Research Council of Canada (SSHRC) and Heritage Canada, included the following:

- Explaining Variance in Second Language Listening: Implications for French Immersion Education (2007-2010),

- Proposal for a Common Framework of Reference for Languages for Canada (2005-2006),

- Teaching Students How to Listen (2003-2007),

- Teaching Listening Comprehension Strategies (1998-2004),

- National Core French Assessment Project (1995-1999),

- Commonalities in Canadian Core French Programs (1994-1995).

As a distinguished researcher, Larry Vandergrift received numerous awards of recognition for his contributions to the field and had noteworthy achievements. Of significance, in 2009, he was the recipient of the prestigious Prix Robert Roy for outstanding contribution to the advancement of L2 education in Canada. In addition, he was 
the Co-editor of the Canadian Modern Language Review (2002-2008) and the Scholar in Residence with the Official Languages Support Program Branch, Canadian Heritage (20052006).

The call for papers for this Special Issue of the Canadian Journal of Applied Linguistics solicited submissions on topics related to the contributions made by Larry Vandergrift to the field of language teaching and learning. More specifically, we were most interested in manuscripts that included theoretical and/or empirical research with clear pedagogical applications in the following areas:

- L1 and L2 listening comprehension, auditory discrimination and memory in the L2;

- metacognition in language learning and teaching;

- L2 assessment and curriculum development;

- FSL learning and teaching; and/or

- the CEFR and DELF in Canada.

\section{Part 2}

\section{Structure and Content of this Special Issue}

For this Special Issue of the Canadian Journal of Applied Linguistics, In Memory of Larry Vandergrift, we have gathered five articles that report on studies related to themes addressed by our late colleague in his research work as well as through his training activities in teaching and learning FSL. We have organized these articles under three main themes: (a) FSL, (b) listening comprehension, and (c) the CEFR.

FSL. Under the first theme dealing with FSL/French as a foreign language (FFL), there are three articles: the first deals with FFL learners' perception of the task-based approach (Caroline Payant, Université du Québec à Montréal); the second with FSL teachers' perception of their professional practices (Usha Viswanathan, Glendon College, York University); and the third with a synthesis of FSL research in elementary and secondary schools in Canada (Stephanie Arnott, University of Ottawa; Mimi Masson, University of Toronto; and Sharon Lapkin, University of Toronto).

The first article, written in French by Payant, is entitled, "Étude de la perception de la perception d'apprenants de français langue étrangère l'approche par tâches et des divers types de tâches." It begins with a review of the task-based approach in language teaching, highlighting the characteristics associated with "the task" as originally identified by authors such as Ellis (2003), Long (1987), and Nunan (2004) and in the light of more recent work (Bygate, 2015; Long, 2015), particularly in FFL (Mangenot \& Soubrié, 2010). The typology proposed by Ellis (2017), which classifies language tasks into various types and on which the subsequent analysis is based, is then explained. The article reports that previous research on perceptions of the advantages and disadvantages of the task-based approach has focused on teachers' perceptions, generally positive, and that to date, few studies have focused on those of language learners. The qualitative analysis seeks to identify these perceptions and, in particular, the types of tasks that generate more interest among learners. The analysis is based on experience in FFL classrooms and the study was conducted with Mexican university learners. Through semi-structured interviews, learners 
were asked to give their assessment of four different types of tasks. The results highlight the strengths and weaknesses of these types of tasks, including learners' preferences for more supervised tasks, with task components that are both individual and collective, as well as authentic in nature. The findings highlight learners' appreciation for listening (Vandergrift, 2011) and pronunciation tasks. Recommendations are proposed for future studies that would examine the complexity of these various types of tasks (Revesz, 2011) and would compare the performance of learners at various levels.

The second article, written by Viswanathan in English, is entitled, "Understanding the Relationship Between Second Language Teacher Beliefs and Their Instructional Practices: A Case Study of Core French Teachers." This article focuses on the beliefs of Core French teachers in relation to their perception of their professional practices. The study is addressed in the context of complexity (Larsen-Freeman, 1997) and self-efficacy (Bandura, 1986) theories. The article first presents work on the professional beliefs and practices of (language) teachers that shows that there is sometimes a gap or are even contradictions between beliefs and practices (Basturkmen, 2012, Gabillon, 2012). Research in FSL in Core French programs in Canada is then reported, showing that few studies have examined the relationship between teachers' beliefs and practices in this context. Rather, many studies highlight practices that focus on language form, grammar, and the use of English in the classroom (Lapkin, MacFarlane, \& Vandergrift, 2009), but with an open attitude towards new approaches, such as the CEFR (Faez et al., 2011; Rehner, 2017). The next section of the article is devoted to defining the fundamental concepts that describe the two theories applied to the context of the study, namely that of Core French teachers in Ontario. The main body of the paper describes a qualitative study that examined the relationship between the beliefs and practices of 13 teachers (Grade 9). The corpus analyzed consists of a questionnaire, observations of classroom practices, and a semidirected interview. The results of the questionnaire present the profile of the teachers, their beliefs about L2 teaching and, in particular, about the communicative approach, and their reported practices. Observation of practices highlights the types of pedagogical interventions of teachers, the use of the L1 by teachers, and the use of the L2 by learners. The analysis section discusses the sense of self-efficacy among the various teachers and focuses on two participants whose results are in striking contrast. The conclusion suggests that practices are aligned with beliefs. However, in periods of chaos (i.e., instability and uncertainty), disparities between beliefs and practices arise and this is particularly among teachers with a low sense of self-efficacy in dealing with complex pedagogical situations (Piccardo, 2010).

The third article, written in English by Arnott, Masson, and Lapkin, is entitled, "Exploring Trends in $21^{\text {st }}$ Century Canadian K-12 FSL Research: A Research Synthesis." This article provides an overview of FSL research in the K-12 context in Canada based on a meta-analysis of publications over a 17-year period (2000-2017). In line with the work of Cooper et al. (2009, 2013), Hedges (2009), and Norris and Ortega (2006), the authors' objective is to provide a comprehensive reference document for decision-makers (government and others) on the research questions already addressed in the literature. The corpus studied consists of 167 articles from: the Canadian Journal of Applied Linguistics, the Canadian Journal of Modern Languages, the Modern Language Review, and the International Journal of Bilingual Education and Bilingualism. The results highlight the themes explored so far in the research, including four main themes: FSL instruction, literacy, French language form, and the profile of FSL learners. A majority of the articles 
analyzed focus on the teaching of French in Immersion and Core French contexts. They deal with, among other things, the use of the L1 (e.g., Lapkin, MacFarlane, $\&$

Vandergrift, 2009), the use of technologies, (bi)literacy, focusing on linguistic form, and strategies for inclusion. While grammar instruction is still important in FSL (Simard \& Jean, 2011), the authors highlight the use of L1 knowledge transfer (e.g., Arnott, 2013) as a strategy for integrating new knowledge into the L2. Further, the authors reveal that the theme of literacy seems to have been mainly addressed in Immersion contexts. Studies show the benefits of Early Immersion on FSL reading and writing skills, as well as the use of the bi/plurilingual repertoire on FSL acquisition (e.g., Chung et al., 2017). The theme of focusing on linguistic form is also mainly addressed in an Immersion context, with Lyster et. al's (2002-2013) research on corrective feedback and explicit instruction dominating this theme. Finally, the theme of learner profile addresses issues related to motivation in FSL programs, for example, gender (Kissau, 2006, 2007). This research focuses on the success of newcomers and multilingual children in FSL programs (e.g., Mady, 2007-2015; Sabatier et al., 2013). The article concludes with recommendations for new research that would target Core French programs, which have remained marginal in the research, and target learning French as an additional language in an Aboriginal context using decolonized methodologies (Smith, 2013).

Listening comprehension. Under the second theme, listening comprehension, the selected article (Yang Li, Guangdong University of Foreign Studies, and Xian Zhang, University of North Texas) focuses on listening comprehension in the L2 and the lexicon.

The article, by Li and Zhang, is written in English and is entitled, "A Structural Equation Model Towards L2 Listening Comprehension and L2 Vocabulary Knowledge." Their study seeks to establish links between listening comprehension and the L2 lexicon: the extent and depth of knowledge of the latter as well as lexical fluency. The authors propose a model that predicts the level of oral proficiency based on lexical proficiency indices. The first part of the article reviews the literature on listening comprehension in relation to lexical knowledge in the L2. Factors such as L1 (Vandergrift, 2006b), motivation, and metacognitive strategies (Vandergrift \& Goh, 2012) that influence oral comprehension in the L2 are highlighted. The discussion then focuses on lexical knowledge as a key factor for reading comprehension (Nation, 2006), knowing that knowledge of 8,000 word-families is a threshold level for reading comprehension (Laufer \& RavenhorstKalovski, 2010). The article shows how several studies have corroborated the positive effect of vocabulary expansion on reading competence, but also on listening comprehension (e.g., Vandergrift \& Baker, 2015). In-depth knowledge of the lexicon allows for better semantic inferences (de Bot, Paribakht, \& Wesche, 1997), with a positive effect on listening comprehension (Stæhr, 2009). Finally, the authors describe how Segalowitz's (2005) research showed that lexical processing speed has a positive effect on oral and written comprehension skills. The second part of the article describes a quantitative analysis that involves a group of 290 English as a second language (ESL) university Chinese learners. The instruments used are: the Peabody Picture Vocabulary Test (PPVT) $4^{\text {th }}$ edition (Dunn $\&$ Dunn, 2007) for the auditory measurement of the extent of lexical knowledge; the Word Associates Test (WAT, Read 1993) for the auditory measurement of the depth of lexical knowledge; an in-house test based on items from the Vocabulary Levels Test (Schmitt, Schmitt, Clapham, 2001); and, the oral comprehension part of the International English Language Testing System (IELTS) for measuring oral 
comprehension. The results presented are based on a technique for modelling structural equations (Byrnes, 2001) that combine lexical variables to predict the effect on listening comprehension competence. These results show a positive correlation between range and depth and lexical fluency and between depth and lexical fluency. In addition, they demonstrate the "predictive skills" of the three lexical dimensions of listening comprehension. The discussion highlights the importance of each of these dimensions for listening comprehension. Pedagogical recommendations are proposed that emphasize work on fluency (speed of lexical recognition) and combined words (collocations, in particular).

The CEFR. Finally, under the theme of the CEFR, the selected article (Enrica Piccardo, University of Toronto; Brian North, Eurocentres Foundation; and Eleonora Maldina, University of Toronto) reports on a comparative study of its application in two distinct national contexts: Canada and Switzerland.

The article, written in English by Piccardo, North, and Maldina, is entitled, "Innovation and Reform in Course Planning, Teaching and Assessment: The CEFR in Canada and Switzerland, A Comparative Study." This article presents the comparative experiences of CEFR integration processes in Canada and Switzerland as part of a research project entitled QualiCEFR. This project aims to encourage a culture of quality assurance in planning, teaching, and evaluation and to identify promising practices in these processes. The authors first recall the primary objectives of the CEFR as a reference tool for: measuring language skills; encouraging innovation in pedagogical practices; and linking curricula, practices and assessment. They then recall the structure of this reference document: the language skills categories and the descriptors that describe them and its new addition to the framework, the CEFR Companion Document (Council of Europe, 2018). The authors then identify the fact that few studies have been conducted on the true impact of the CEFR on curricula in those countries interested in the CEFR and its implementation. The Canadian case is described in detail, from the Vandergrift (2006a) report which recommended its adoption, to its effective adoption in the curricula of the various provinces, namely in FSL programs (Arnott et al., 2017). The authors point out that several studies have highlighted the interest of FSL teachers in the CEFR (e.g., Kristmanson, Lafargue, \& Culligan, 2011) and that others have reported experiences of practical application of the CEFR (through its Portfolio or the task-based approach, for example). It should also be noted that CEFR is a vehicle for dialogue on language education between the provinces (CMEC, 2015). The comparative study is then presented. This is a qualitative analysis of 44 interviews conducted with various stakeholders (principals, trainers, teachers, etc.) in two countries, namely Canada and Switzerland. The shared themes for discussion highlighted by this analysis are: plurilingualism, skills, levels, can-do descriptors, communicative and task-based approaches, and criterion-based evaluation. The results are discussed in light of two research questions: one on the implementation processes of the CEFR and the other on those processes that are most successful. With regard to the latter, we note the importance of teacher training, the introduction of examinations external to training (such as the DELF) for the recognition of prior learning, and the scientific and administrative monitoring in these processes. The authors conclude by stressing the need to provide individuals involved in innovation, often teachers (Moonen et al., 2013), with quality assurance tools in order to facilitate and energize the innovation cycle (North et al., 2018). 


\section{Part 3}

\section{Concluding Remarks}

We thank the authors of these five articles for their contributions to this Special Issue of the Canadian Journal of Applied Linguistics, In Memory of Larry Vandergrift and the anonymous reviewers for their valuable comments and suggestions. We also extend a warm thank you to the journal's editorial team and in particular to Karla Culligan for her efficient and thorough work.

\section{References to Publications by Larry Vandergrift Cited in this Introduction}

Lapkin, S., MacFarlane, A., \& Vandergrift, L. (2006). Teaching French in Canada: FSL teachers' perspectives. Ottawa, Canada: Canadian Teachers' Federation. Retrieved from https://www.caslt.org/files/pd/resources/research/2006-teaching-fsl-in-canadaen.pdf

Vandergrift, L. (2006a). New Canadian perspectives: Proposal for a common framework of reference for languages in Canada. Ottawa, Canada: Department of Canadian Heritage/Patrimoine canadien. Retrieved from: http://publications.gc.ca/collections/collection_2011/pc-ch/CH4-114-2006-eng.pdf

Vandergrift, L. (2006b). Second language listening: Listening ability or language proficiency? The Modern Language Journal, 90, 6-18.

Vandergrift, L. (2011). Second language listening: Presage, process, product, and pedagogy. In E. Hinkel (Ed.), Handbook of research in second language teaching and learning (Vol. 2, pp. 455-471). New York, NY: Routledge.

Vandergrift, L., \& Baker, S. (2015). Learner variables in second language listening comprehension: An exploratory path analysis. Language Learning, 65(2), 390-416.

Vandergrift, L., \& Goh, C. (2012). Teaching and learning second language listening: Metacognition in action. New York, NY: Routledge.

Vandergrift, L., Goh, C., Mareschal, C., \& Tafaghodtari, M. (2006) The Metacognitive Awareness Listening Questionnaire: Development and validation. Language Learning, 56(3), 431-462.

\section{NB. All other references can be found in the articles themselves.}

Dr. Larry Vandergrift 